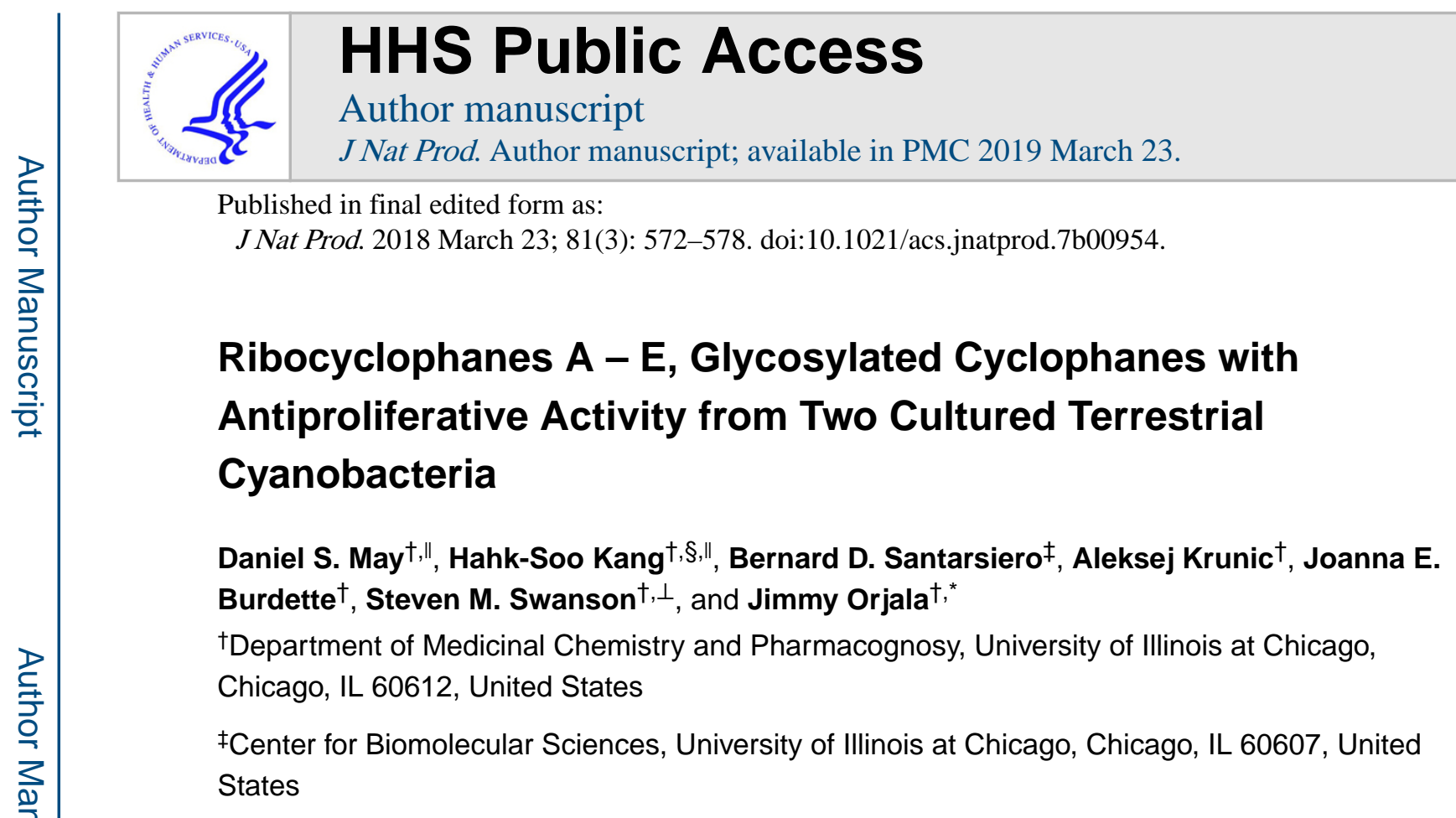

\begin{abstract}
The cell extracts of two cultured freshwater Nostoc spp., UIC 10279 and UIC 10366, both from the suburbs of Chicago, showed antiproliferative activity against MDA-MB-231 and MDA-

MB-435 cancer cell lines. Bioassay-guided fractionation led to the isolation of five glycosylated cylindrocyclophanes, named ribocyclophanes A - E (1 - 5) and cylindrocyclophane D (6). The structure determination was carried out by HRESIMS, and 1D and 2D NMR analyses, and confirmed by a single crystal X-ray crystallography. The structures of ribocyclophanes A - E (1 5) contain a $\beta$-D-ribopyranose glycone in the rare ${ }^{1} C_{4}$ conformation. Among isolated compounds, ribocyclophane D (4) showed antiproliferative activity against MDA-MB-435 and MDA-MB-231 cancer cells with an $\mathrm{IC}_{50}$ value of less than $1 \mu \mathrm{M}$.
\end{abstract}

\title{
SYNOPSIS TOC
}

\footnotetext{
${ }^{*}$ To whom correspondence should be addressed. Tel: +1-312-996-5583. Fax: +1-312-996-7107. orjala@uic.edu.

$\S_{\text {Current Address: }}$

Department of Biomedical Sciences and Engineering, Konkuk University, Seoul 05029, Korea

$\perp_{\text {Current Address: }}$

School of Pharmacy, University of Wisconsin at Madison, Madison, WI 53705, United States

"Contributed Equally

Dedicated to Susan Band Horwitz, of Albert Einstein College of Medicine, Bronx, NY, for her pioneering work on bioactive natural products.

Supporting Information Available. Taxonomic identification and phylogenetic tree of UIC 10279 and UIC 10366 strains; ${ }^{1} \mathrm{H}$ NMR, COSY, HSQC, HMBC spectra of $\mathbf{1}-\mathbf{5}$; DEPT-Q spectrum of $\mathbf{1}$ and $\mathbf{4}$, ECD spectra of $\mathbf{1}-\mathbf{5}$, and antiproliferative data for $\mathbf{1}-\mathbf{6}$ against MDA-MB-435 and MDA-MB-231 cancer cell lines. The Supporting Information is available free of charge on the ACS Publications website at DOI:
} 

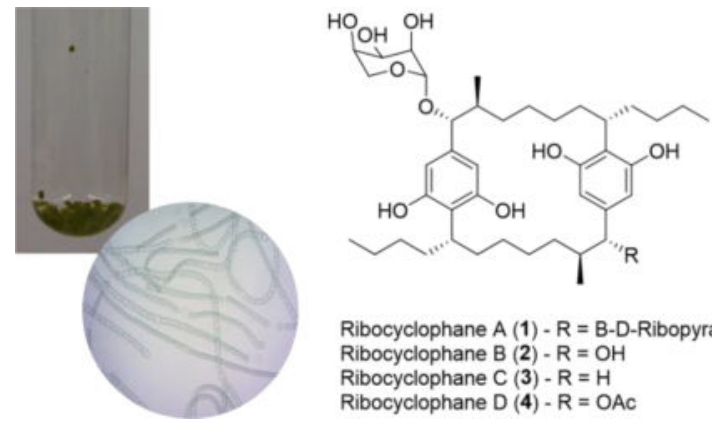

Ribocyclophane A (1) - R = B-D-Ribopyranose

Ribocyclophane $\mathrm{B}(2)-\mathrm{R}=\mathrm{OH}$

Ribocyclophane $\mathrm{C}(3)-\mathrm{R}=\mathrm{H}$

Ribocyclophane D (4) - R = OAC

Polyketides (PK), one of the largest families of natural products, are not commonly found in cyanobacteria compared to other major natural products families, such as non-ribosomal peptides (NRP) and PK-NRP hybrids. ${ }^{1-3}$ However, [7.7]paracyclophanes represent a family of cyanobacterial polyketides that has been found in heterocyst-forming cyanobacteria of the order Nostocales. ${ }^{4-11}$ The 22-membered [7.7]paracyclophane core structure, possessing a $C_{2}$ axis of symmetry, has been shown to be produced by dimerization of two halogenated alkylresorcinol units made by a Type I / Type III polyketide synthase hybrid. ${ }^{12-14}$ The alkylresorcinol units, termed cylindrofridins, were isolated by Preisitsch et al. and proposed as biosynthetic intermediates. ${ }^{15}$ The identification of the biosynthetic intermediates by Nakamura et al. confirmed the biosynthetic origin of these alkyl-resorcinol units as well as their dimerization. ${ }^{13,14,16}$ The core [7.7]paracyclophane structure is further modified by tailoring steps such as methylation, acetylation, carbamate formation, glycosylation and/or halogenation, to generate diverse structural variants. ${ }^{17}$ Cyanobacterial cyclophanes have been shown to possess a broad range of biological activities, including antibacterial, antifungal and cytotoxic activities. ${ }^{6-11}$

Several Nostoc spp. from the University of Illinois at Chicago (UIC) cyanobacterial library have been identified to produce [7.7]paracyclophanes. Chlorinated cylindrocyclophanes were obtained from Nostoc sp. (UIC 10022A). ${ }^{7}$ These chlorinated cyclindrocyclophanes exhibited $20 \mathrm{~S}$ proteasome-inhibitory activity and cytotoxicity against several cancer cell lines. Carbamidocyclophanes F and G were reported from UIC 10274, containing terminal chlorines as well as an uncommon carbamate moiety. ${ }^{10}$ In addition, the isolation of merocyclophanes A and B from Nostoc sp. (UIC 10062) from Grand Mere State Park in Michigan was reported, as well as merocyclophanes C and D from the extract of UIC 10110, a Nostoc sp. from Colorado. Merocyclophanes A-D featured a new [7.7]paracyclophane carbon skeleton characterized by the presence of branched methyls at a positions (C-1/14). 8,11 The extract of a cultured Nostoc sp. (UIC 10279), obtained from a sample collected in the southwest suburbs of Chicago, displayed antiproliferative activity against the human melanoma cancer cell line MDA-MB-435. HPLC-based activity profiling followed by LCMS and ${ }^{1} \mathrm{H}$ NMR-based dereplication suggested the presence of three glycosylated cyclophanes as active metabolites. Concurrently, a second Nostoc sp. (UIC 10366), obtained from a collection in the northwestern suburbs of Chicago, also displayed antiproliferative activity against MDA-MB-435 cancer cells. LCMS and ${ }^{1} \mathrm{H}$ NMR-based dereplication also suggested the presence of glycosylated cyclophanes similar to UIC 10279, including one unique to UIC 10366. During isolation, a fifth minor compound was identified from UIC 
10366. Herein, we report the isolation, structure determination and antiproliferative activities of five glycosylated cyanobacterial [7.7]paracyclophanes, named ribocyclophanes A - E (1 5).

\section{Results and Discussion}

Strain UIC 10279 was obtained from a sample collected southwest of Chicago near the suburb of Joliet, Illinois, while strain UIC 10366 was obtained from a sample collected near Elgin, Illinois, a suburb northwest of Chicago. The strains were both designated as Nostoc sp. based on morphological and 16S rRNA gene sequence analysis (Supporting Information, $\mathrm{S} 1$ and S2). Each strain was cultured in $\mathrm{Z}$ media, ${ }^{18}$ and the freeze-dried cells were extracted with a mixture of $\mathrm{CH}_{2} \mathrm{Cl}_{2}$ and $\mathrm{MeOH}(1: 1, \mathrm{v} / \mathrm{v})$. The resulting extracts displayed antiproliferative activity against the MDA-MB- 435 cancer cell line. Both extracts were fractionated using Diaion HP-20 resin with an increasing amount of $i \operatorname{PrOH}$ in $\mathrm{H}_{2} \mathrm{O}$. Fractions eluting at 50\% and $60 \%$ iPrOH showed antiproliferative activity for both strains. To facilitate the identification of potentially active compounds, the active fractions were subjected to our HPLC-based activity profiling that combines HPLC-based fractionation in a 96 well plate with the cell-based activity assay. Three active compounds were identified in each strain. Dereplication of the active fractions of UIC 10279 by LC-MS and ${ }^{1} \mathrm{H}$ NMR spectroscopy indicated the presence of glycosylated cyclophanes with molecular weights of 848,716 and 700 Da. Dereplication of the active peaks of UIC 10366 by LC-MS and ${ }^{1} \mathrm{H}$ NMR spectroscopy indicated the presence of the previously reported cylindrocyclophane D as well as two potentially new glycosylated cyclophanes with molecular weights of $848 \mathrm{Da}$ and $758 \mathrm{Da}^{4}$ Active fractions for each strain were subjected to reversed-phase HPLC to yield six pure compounds between the two extracts. During isolation from the extract of UIC 10366, a low abundance compound, ribocyclophane E (5), was also obtained.

Ribocyclophanes A $(\mathbf{1}, 0.5 \%), \mathrm{B}(\mathbf{2}, 0.1 \%)$ and C (3, 0.3\%) were isolated from UIC 10279, and ribocyclophanes $\mathrm{A}(\mathbf{1}, 0.5 \%), \mathrm{D}(\mathbf{4}, 0.5 \%), \mathrm{E}(\mathbf{5},<0.1 \%)$ as well as the known compound cylindrocyclophane D $(\mathbf{6}, 0.2 \%)$ were isolated from UIC 10366.

Ribocyclophane A (1), a white amorphous powder obtained from UIC 10279, displayed a deprotonated molecule at $\mathrm{m} / \mathrm{z} 847.4895\left([\mathrm{M}-\mathrm{H}]^{-}\right)$in HRESIMS analysis, corresponding to a molecular formula of $\mathrm{C}_{46} \mathrm{H}_{71} \mathrm{O}_{14}$. The ${ }^{1} \mathrm{H}$ NMR spectrum of $\mathbf{1}$ showed signals characteristic of cylindrocyclophanes with two singlet aromatic protons $\left(\mathrm{H}-10 / 23, \delta_{\mathrm{H}} 6.19 ; \mathrm{H}-12 / 25, \delta_{\mathrm{H}}\right.$ 6.09), benzylic doublet and multiplet methines $\left(\mathrm{H}-1 / 14, \delta_{\mathrm{H}} 3.65 ; \mathrm{H}-7 / 20, \delta_{\mathrm{H}} 3.16\right)$, shielded diastereotopic methylenes $\left(\mathrm{H}_{2}-3 / 16\right.$ and $\left.\mathrm{H}_{2}-5 / 18, \delta_{\mathrm{H}} 0.5-1.0\right)$ and a doublet methyl $\left(\mathrm{H}_{3}-35 / 36, \delta_{\mathrm{H}} 1.05\right)$. Only half the number of signals were observed in the ${ }^{1} \mathrm{H}$ and ${ }^{13} \mathrm{C}$ NMR spectra, as indicated by the molecular formula, suggesting the presence of an element of symmetry in $\mathbf{1}$. The ${ }^{1} \mathrm{H}$ NMR spectrum of $\mathbf{1}$ showed an additional set of proton signals adjacent to oxygen $\left(\delta_{\mathrm{H}} 3.0-4.0\right)$ and an anomeric proton $\left(\delta_{\mathrm{H}} 4.85\right)$ compared to those observed for the cylindrocyclophanes, suggesting the presence of a glycoside moiety in $\mathbf{1}$. The structure and position of a sugar moiety were determined by 2D NMR analysis. Sequential COSY correlations from the anomeric proton H-1'/6' $\left(\delta_{\mathrm{H}} 4.85\right)$ to the diastereotopic methylene protons $\mathrm{H}_{2}{ }^{\prime}{ }^{\prime} / 10^{\prime}$ ( $\left(\delta_{\mathrm{H}} 3.19\right.$ and 3.30) via three hydroxylated methine protons, $\mathrm{H}-2^{\prime} / 7^{\prime}\left(\delta_{\mathrm{H}} 3.73\right), \mathrm{H}-3^{\prime} / 8^{\prime}\left(\delta_{\mathrm{H}} 3.70\right)$ and $\mathrm{H}-4^{\prime} / 9^{\prime}\left(\delta_{\mathrm{H}} 3.59\right)$, together with an $\mathrm{HMBC}$ correlation from $\mathrm{H}_{2}-5^{\prime} / 10^{\prime}$ to $\mathrm{C}^{-1} 1^{\prime} / 6^{\prime}$, indicated the sugar moiety to be a 
pentopyranose (Figure 1). The HMBC correlation observed from the anomeric protons $\mathrm{H}-1$ '/6' to C-1/14 established the linkage between the pentopyranose and the cylindrocyclophane aglycone.

To determine the relative configuration of the sugar moiety, ${ }^{3} \mathrm{JHH}_{\mathrm{HH}}$ analysis and an NOE experiment were initially attempted. The small ${ }^{3} J_{\mathrm{HH}}$ value $(1.8 \mathrm{~Hz})$, observed between $\mathrm{H}-1^{\prime} / 6^{\prime}$ and $\mathrm{H}-2^{\prime} / 7^{\prime}$ indicated that these two protons are in an either ax-eq or eq-eq relationship. The ${ }^{3} J_{\mathrm{HH}}$ values between H-2'/7', H-3'/8' and H-4'/9' could not be measured directly from the ${ }^{1} \mathrm{H}$ NMR spectrum due to the broad signals observed; however, the broad line shapes of NMR signals observed for all of the signals indicated small ${ }^{3} J_{\mathrm{HH}}$ values between these protons. In addition, no NOE correlation was observed between $\mathrm{H}-1^{\prime} / 6^{\prime}$ and H-3'/8', and between H-2'/7' and H-4'/9', complicating the determination of the relative configuration for the sugar moiety. To unambiguously determine the ${ }^{3} J_{\mathrm{HH}}$ values of the glycone moiety, spin simulation was performed using Spinworks. The ${ }^{3} J_{\mathrm{HH}}$ values measured using spin simulation were 3.0 (H-2'/7' and H-3'/8'), 3.0 (H-3'/8' and H-4'/9'), 1.2 (H-4'/9' and $\mathrm{H}-5$ ' a/10'a) and $2.4 \mathrm{~Hz}$ (H-4'/9' and H-5'b/10'b), respectively. These small $J$ values clearly demonstrated that all the protons are in ax-eq or eq-eq relationships, thus suggesting $\beta$-D-ribopyranose $\left({ }^{1} C_{4}\right), \beta$-L-ribopyranose $\left({ }^{4} C_{1}\right), \beta$-D-xylopyranose $\left({ }^{1} C_{4}\right)$ or $\beta$-L-

xylopyranose $\left({ }^{4} C_{1}\right)$ as a possible glycone moiety. All of these possible sugar moieties adopt thermodynamically unfavorable conformations where three or all four oxygen atoms are in axial positions. To unambiguously disclose the relative configuration of the sugar moiety as well as its spatial conformation, single crystal $\mathrm{X}$-ray crystallographic analysis was carried out using a crystal obtained from a mixture of $\mathrm{EtOH}$ and $\mathrm{H}_{2} \mathrm{O}$ (1:1) by slow evaporation. The crystal structure (Figure 2) of $\mathbf{1}$ revealed that the relative configuration of the glycone moiety is a $\beta$-ribopyranose where oxygen atoms at C-1', C-2' and C-4' were axially positioned. The absolute configuration of $\mathbf{1}$ was determined by measuring the optical rotation of the glycone moiety and ECD analysis of the aglycone moiety, each liberated by acid hydrolysis $(1 \mathrm{~N} \mathrm{HCl})$. The negative rotation $\left([a]_{D}-9\right)$, observed for the glycone moiety, indicated the absolute configuration to be a $\beta$-D-ribopyranose with ${ }^{1} C_{4}$ conformation (Figure 2). Negative Cotton effects observed at $230 \mathrm{~nm}$ and $280 \mathrm{~nm}$ for the aglycone moiety are identical to those observed for cylindrocyclophane A, indicating the same absolute configuration. ${ }^{6}$ The potential energy of a ${ }^{1} C_{4}$ conformation is approximately four times higher than that of ${ }^{4} C_{1}$ conformation for $\beta$-D-ribopyranose. ${ }^{19}$ The adoption of a thermodynamically unfavorable conformation for the glycone moiety could be rationalized by a favored spatial arrangement to avoid a steric interaction between the algycone and glycone moieties in the overall structure (Figure 3 ). The $\beta$-D-ribopyranose glycone with the preferred ${ }^{4} C_{1}$ conformation occupies a much larger spatial volume than that with a ${ }^{1} C_{4}$ conformation, creating a steric effect with the aromatic ring and branched methyl of the cylindrocyclophane aglycone. This steric effect forces the sugar moiety into a ${ }^{1} C_{4}$ conformation, and the adoption of a ${ }^{1} C_{4}$ conformation increases the overall stability of $\mathbf{1}$ by reducing the spatial volume of the glycone moiety. The selection of the unfavorable ${ }^{1} C_{4}$ conformation is also supported by the anomeric effect, in which heteroatom substituents preferentially assume an axial orientation when adjacent to a heteroatom within a ring. The glycone moiety of $\mathbf{1}$ obtained from UIC 10366 was found to have the same negative specific rotation and identical ${ }^{1} \mathrm{H}$ NMR signals as those observed for $\mathbf{1}$ from UIC 10279, suggesting 
that the glycone produced by UIC 10366 is also a $\beta$-D-ribopyranose. The crystal structure of 1 allowed the assignment of the stereocenters of the cylindrocyclophane aglycone as $1 R, 2 S$, $7 R, 14 R, 15 S, 20 R$ which are identical to those reported for cylindrocyclophane A.

Ribocyclophane B (2) was obtained as a white amorphous powder from UIC 10279, and HRESIMS analysis $\left(\mathrm{m} / \mathrm{z} 715.4477[\mathrm{M}-\mathrm{H}]^{-}\right)$suggested the molecular formula of $\mathbf{2}$ as $\mathrm{C}_{41} \mathrm{H}_{64} \mathrm{O}_{10}$. The ${ }^{1} \mathrm{H}$ NMR spectrum of $\mathbf{2}$ showed the overall signal distribution pattern similar to that observed for 1 . The appearance of four singlet aromatic $\left(\delta_{\mathrm{H}} 6.07,6.09,6.20\right.$ and 6.24) and two doublet methyl ( $\delta_{\mathrm{H}} 1.05$ and 1.06) signals indicated the structure of 2 to be non-symmetrical. The integration of each signal of the glycone moiety corresponded to that of one aromatic proton signal of the aglycone moiety, suggesting the presence of only one sugar moiety in 2 . The newly appeared signal of $\mathrm{H}-14\left(\delta_{\mathrm{H}} 3.74\right)$ compared to $\mathbf{1}$, together with the mass difference of 132 between $\mathbf{2}$ and $\mathbf{1}$, demonstrated that one of the glycoside moieties in $\mathbf{1}$ was replaced by a hydroxy group in $\mathbf{2}$. The ECD spectrum of $\mathbf{2}$, showed positive Cotton effects at 221 and $275 \mathrm{~nm}$, identical to those observed for $\mathbf{1}$, suggesting the same absolute configuration for $\mathbf{2}$.

Ribocyclophane C (3) was obtained as a white amorphous powder from UIC 10279. HRESIMS analysis $\left(\mathrm{m} / \mathrm{z} 699.4533[\mathrm{M}-\mathrm{H}]^{-}\right)$suggested the molecular formula of $\mathbf{3}$ as $\mathrm{C}_{41} \mathrm{H}_{64} \mathrm{O}_{9}$. The ${ }^{1} \mathrm{H}$ NMR spectrum of $\mathbf{3}$ closely resembled that of $\mathbf{2}$, and four aromatic and two doublet methyl signals were observed, thus indicating the structure of $\mathbf{2}$ to be also nonsymmetrical due to the presence of one glycone moiety. The notable difference was the replacement of an oxygenated methine proton $\mathrm{H}-14$ in 2 by diastereotopic methylene protons ( $\delta_{\mathrm{H}} 1.81$ and 2.61) in $\mathbf{3}$. This, together with the 16 mass difference between $\mathbf{2}$ and $\mathbf{3}$, which corresponded to one oxygen atom, suggested the absence of the hydroxy group at C-14. This was confirmed by NMR analysis (Table 2), demonstrating the structure of $\mathbf{3}$ to be the deoxygenated analogue of $\mathbf{2}$. The positive Cotton effects observed at 222 and $274 \mathrm{~nm}$ indicated the same absolute configuration of $\mathbf{3}$ as determined for $\mathbf{2}$.

Ribocyclophane D (4) was obtained as a white amorphous powder from UIC 10366. HRESIMS analysis $\left(\mathrm{m} / \mathrm{z} 757.4489[\mathrm{M}-\mathrm{H}]^{-}\right)$suggested the molecular formula of $\mathbf{4}$ as $\mathrm{C}_{43} \mathrm{H}_{66} \mathrm{O}_{11}$. The ${ }^{1} \mathrm{H}$ NMR spectrum of $\mathbf{4}$ was similar to that of $\mathbf{2}$ and $\mathbf{3}$, suggesting the compound was non-symmetrical due to differing moieties on the cylindrocyclophane scaffold. The difference in molecular formula between $\mathbf{2}$ and $\mathbf{4}$ suggested the presence of an acetate group. The presence of a singlet at $\delta_{\mathrm{H}} 2.0$ in the ${ }^{1} \mathrm{H}$ NMR spectrum and signals at $\delta_{\mathrm{C}}$ 21.3 and $\delta_{\mathrm{C}} 172.6$ in the ${ }^{13} \mathrm{C}$ NMR spectrum confirmed the presence of an acetate moiety. HMBC correlations from H-14 to C-37 confirmed the placement of the acetate moiety a to the resorcinol core. The positive Cotton effects observed at 222 and $273 \mathrm{~nm}$ indicated the same absolute configuration as all previously described [7.7]paracyclophanes.

Ribocyclophane E (5) was obtained as a minor component from UIC 10366 during the isolation of 4. HRESIMS analysis showed an isotopic pattern consistent with the presence of one chlorine atom and suggested a molecular formula of $\mathrm{C}_{43} \mathrm{H}_{67} \mathrm{ClO}_{11}(\mathrm{~m} / z 793.9098[\mathrm{M}-\mathrm{H}]$ - and $795.9101[\mathrm{M}-\mathrm{H}]^{-}$in a 3:1 ratio). Comparing the ${ }^{1} \mathrm{H}$ NMR spectrum to the spectra for $\mathbf{1}$ - 4 indicated 5 to be structurally different. The ${ }^{1} \mathrm{H}$ NMR spectrum of 5 was more similar to the ${ }^{1} \mathrm{H}$ NMR spectra of the cylindrofridins published by Preisitsch et al. ${ }^{15}$ NMR analysis 
allowed the assignment of two aliphatic chains as well as a ribose. The signal at $\delta_{\mathrm{H}} 3.83$ indicated a proton adjacent to a halogen, suggesting the presence of the chlorine atom on one of the aliphatic chains. HSQC and ${ }^{13} \mathrm{C}$ spectra confirmed the presence of the chlorine, with the signal at $\delta_{\mathrm{H}} 3.83$ correlating to $\mathrm{C}-7$ at $\delta_{\mathrm{C}} 65.1$. COSY correlations from H-7 to H-6 and $\mathrm{H}-27$ confirmed the placement of the chlorine along the aliphatic chain. The presence and positions of two resorcinol-like groups were deduced by HMBC correlations from $\mathrm{H}-23 / 25$ to $\mathrm{C}-1$ and likewise from $\mathrm{H}-10 / 12$ to $\mathrm{C}-14$, and $\mathrm{H}-20$ to $\mathrm{C}-22 / 26$ and $\mathrm{H}-31 / 19$ to C-21. No correlations were observed from H-7 to C-9/13 or H-6/27 to C-8, as would be present in other [7.7]paracyclophane HMBC spectra. This is consistent with cylindrofridinlike structures that are linear. $\mathrm{HMBC}$ correlation from $\mathrm{H}-1$ to $\mathrm{C}-1$ ' confirmed the position of the ribose and a correlation from $\mathrm{H}-14$ to $\mathrm{C}-37$, along with the strong singlet signal at $\delta_{\mathrm{H}}$ 2.07 , suggested the presence of an acetate moiety. The Cotton effects observed at 222 and $274 \mathrm{~nm}$ indicated the same absolute configuration as the previously described cylindrofridins and [7.7]paracyclophanes. ${ }^{15}$ We were unable to establish the configuration of the chiral center at C-7.

Ribocyclophanes A - D (1-4) are glycosylated analogues of the cyclindrocyclophanes. Ribocyclophane E (5) is a glycosylated analog of the cylindrofridins, and a likely biosynthetic intermediate of 4 . A notable structural feature of $\mathbf{1}-\mathbf{4}$ is the presence of a $\beta$-Dribopyranose glycone moiety linked to the benzoyl carbon of the cylindrocyclophane aglycone. This glycone moiety exclusively adopted the thermodynamically unfavorable ${ }^{1} C_{4}$ conformation in which three oxygen atoms are in an axial position and one oxygen atom is in an equatorial position. The crystal structure of $\mathbf{1}$ showed that no hydrogen bonding is involved between the glycone and aglycone moieties to favor the shift of conformational equilibrium toward ${ }^{1} C_{4}$ conformation. This suggested that an avoidance of steric crowding between the $\beta$-D-ribopyranose glycone and the cylindrocyclophane aglycone is likely to be the major driver of the adoption of the ${ }^{1} C_{4}$ conformation.

Ribocyclophanes A - E (1 - 5) and cylindrocyclophane D (6) were tested for their antiproliferative activity against MDA-MB-231 and MDA-MB-435 cancer cell lines.

Ribocyclophane $\mathrm{D}(4)$ showed the strongest activity among six compounds with $\mathrm{IC}_{50}$ values of less than $1 \mu \mathrm{M}$ in both cell lines ( $\mathrm{IC}_{50} 0.8 \mu \mathrm{M}$ and $0.6 \mu \mathrm{M}$, respectively), whereas moderate activity was observed for ribocyclophane $\mathrm{C}(3)\left(\mathrm{IC}_{50} 1.2 \mu \mathrm{M}\right.$ and $1.3 \mu \mathrm{M}$, respectively). Ribocyclophane E (5) showed no antiproliferative activity against either cell line at $25 \mu \mathrm{M}$, corroborating the findings of Preisitsch et al. that an unclosed [7.7]paracyclophane core structure does not retain antiproliferative activity. ${ }^{15}$ Ribocyclophanes A, B, and cylindrocyclophane D all had modest activity against the two cell lines as shown in Supporting Information S18. Interestingly, the large glycone moieties do not seem to change the antiproliferative activity, as ribocyclophane $\mathrm{D}$ has similar activity levels as smaller [7.7]paracyclophanes such as the merocyclophanes. ${ }^{8,11}$

\section{Experimental Section}

\section{General Experimental Procedures}

Optical rotations were measured on a Perkin-Elmer 241 polarimeter. ECD spectra were recorded on a Jasco J-710 ECD spectrometer. UV and IR spectra were recorded on a 
Shimadzu UV spectrometer UV2401 and a Thermo Nicolet 6700 FT-IR spectrometer, respectively. 1D and 2D NMR spectra including ${ }^{1} \mathrm{H}$ NMR, COSY, TOCSY, HSQC, HMBC and T-ROESY spectra were obtained on a Bruker Avance $600 \mathrm{MHz}$ NMR spectrometer with a $5 \mathrm{~mm}$ CPTXI Z-gradient probe, whereas a Bruker Avance II $900 \mathrm{MHz}$ NMR spectrometer with a $5 \mathrm{~mm}$ ATM CPTCI Z-gradient probe was used to acquire the DEPT-Q spectrum. ${ }^{1} \mathrm{H}$ and ${ }^{13} \mathrm{C}$ NMR chemical shifts were referenced to the DMSO- $d_{6}$ solvent signals $\left(\delta_{\mathrm{H}} 2.49\right.$ and $\delta_{\mathrm{C}} 39.7$, respectively) or $\mathrm{MeOH}-d_{4}$ solvent signals ( $\delta_{\mathrm{H}} 3.31$ and $\delta_{\mathrm{C}} 49.15$, respectively). A mixing time of $60 \mathrm{~ms}$ was set for the TOCSY experiment and $200 \mathrm{~ms}$ for the T-ROESY experiment. The $\mathrm{HMBC}$ spectrum was recorded with the average ${ }^{3} J_{\mathrm{CH}}$ of $8 \mathrm{~Hz}$ and the HSQC spectrum was measured with the average ${ }^{1} J_{\mathrm{CH}}$ of $145 \mathrm{~Hz}$. HRESIMS and LC-MS data were obtained on a Shimadzu IT-TOF LC-MS spectrometer.

\section{Biological Material}

Nostoc sp. (UIC 10279) was isolated from a sample collected in the southwest suburbs of Chicago near the town of Joliet, Illinois. The unialgal strain (UIC 10279) was produced through micropipette isolation techniques. ${ }^{20}$ Taxonomic identification of the strain UIC 10279 was carried out using a partial 16S rRNA gene sequence (GenBank Accession No. JX962720, See SI, S2). Nostoc sp. (UIC 10366) was isolated from a sample collected in the northwest suburbs of Chicago near the town of Elgin, Illinois, through micropipette isolation. ${ }^{20}$ Taxonomic identification of the strain UIC 10366 was carried out using a partial 16S rRNA gene sequence (GenBank Accession No. MF622942, see SI, S2). Both strains were cultured in four $2.8 \mathrm{~L}$ Fernbach flasks each containing inorganic $\mathrm{Z}$ media $(4 \times 2 \mathrm{~L})$ with sterile aeration. ${ }^{18}$ Cultures were illuminated with fluorescent lamps at $1.03 \mathrm{klx}$ with an $18 / 6 \mathrm{~h} \mathrm{light/dark}$ cycle. The temperature of the culture room was maintained at $22{ }^{\circ} \mathrm{C}$. After 7 weeks, the biomasses were harvested by centrifugation and then freeze-dried.

\section{Extraction and Isolation}

The freeze-dried cells were each extracted with $\mathrm{CH}_{2} \mathrm{Cl}_{2}-\mathrm{MeOH}(1: 1 \mathrm{v} / \mathrm{v})$ three times and concentrated in vacuo to yield organic extracts ( $0.5 \mathrm{~g}$ of UIC 10279 and $0.65 \mathrm{~g}$ of UIC 10366). The resulting extracts were fractionated using Diaion HP-20 resin with an increasing amount of $\mathrm{PrOH}$ in $\mathrm{H}_{2} \mathrm{O}$. The fractions eluting at $50 \%$ and $60 \% \mathrm{iPrOH}$ were found to be active in the antiproliferative assay against MDA-MB-435 cells (95\% and 97\% at $25 \mu \mathrm{g} / \mathrm{mL}$, respectively). HPLC-based activity profiling of the active fractions, which associates the HPLC chromatogram with biological activity, identified three active peaks for each strain. Dereplication of these peaks by LC-MS and ${ }^{1} \mathrm{H}$ NMR indicated these peaks to be new cyclophanes with the molecular weights of 848, 758, 716 and $700 \mathrm{Da}$. The fractions containing active peaks were combined and subjected to reversed-phase HPLC (Varian $C_{8}$ column, $10 \mathrm{~mm} \times 250 \mathrm{~mm}, 3 \mathrm{~mL} / \mathrm{min}$ ) eluting with gradient using aqueous $\mathrm{MeOH}$ from 60 to $80 \%$ over 40 min which led to the isolation of ribocyclophanes A $(1,15 \mathrm{mg}, 0.5 \%)$, B (2, $3 \mathrm{mg}, 0.1 \%)$, and C (3,10 mg, $0.3 \%)$ from UIC 10279; and ribocyclophanes D $(\mathbf{4}, 15 \mathrm{mg}$, $0.5 \%), \mathrm{E}(\mathbf{5}, 1 \mathrm{mg},>0.1 \%)$, and cylindrocyclophane D (6, $6 \mathrm{mg}, 0.2 \%)$ from UIC 10366.

Ribocyclophane $A$ (1): white amorphous powder; $[a]^{25} \mathrm{D}$ - $6(c 0.12, \mathrm{MeOH})$; UV $(\mathrm{MeOH})$ $\lambda_{\max }(\log \varepsilon) 208$ (4.41), 223 (3.88), $276(3.13) \mathrm{nm}$; ECD (MeOH $\left.1.0 \mathrm{mM}\right) \lambda_{\max }(\Delta \varepsilon) 208$ (2.87), 224 (1.27), $282(1.04) \mathrm{nm}$; IR (neat) $v_{\max } 3365,2930,2857,1628,1432,1381,1321$ 
$\mathrm{cm}^{-1}$; $1 \mathrm{H}$ and ${ }^{13} \mathrm{C}$ NMR, COSY, and HMBC data, Table 1; HRESIMS $\mathrm{m} / \mathrm{z} 847.4894$ [M-H] - (calcd for $\mathrm{C}_{46} \mathrm{H}_{71} \mathrm{O}_{14}, 847.4844$ ). Spectroscopic data of $\mathbf{1}$ isolated from UIC 10366 was identical to that from UIC 10279.

Ribocyclophane $B(2)$ : white amorphous powder; $[a]^{25} \mathrm{D}-6(c 0.07, \mathrm{MeOH}) ; \mathrm{UV}(\mathrm{MeOH})$ $\lambda_{\max }(\log \varepsilon) 207$ (4.10), 221 (3.65), $275(2.90) \mathrm{nm}$; ECD (MeOH $\left.0.7 \mathrm{mM}\right) \lambda_{\max }(\Delta \varepsilon) 208$ (1.62), 222 (0.99), 284 (0.86) nm; IR (neat) $v_{\max } 3378,2930,2858,1631,1469,1432,1372$ $\mathrm{cm}^{-1} ;{ }^{1} \mathrm{H}$ and ${ }^{13} \mathrm{C}$ NMR data, Table 2; HRESIMS $\mathrm{m} / \mathrm{z} 715.4471[\mathrm{M}-\mathrm{H}]^{-}$(calcd for $\mathrm{C}_{41} \mathrm{H}_{63} \mathrm{O}_{10}, 715.4421$ )

Ribocyclophane $C(3)$ : white amorphous powder; $[a]^{25} \mathrm{D}+6(c 0.16, \mathrm{MeOH}) ; \mathrm{UV}(\mathrm{MeOH})$ $\lambda_{\max }(\log \varepsilon) 209$ (4.54), $223(4.03), 275(3.23) \mathrm{nm}$; ECD (MeOH $\left.0.7 \mathrm{mM}\right) \lambda_{\max }(\Delta \varepsilon) 211$ (2.59), 224 (1.44), 282 (2.00) nm; IR (neat) $v_{\max }$ 3382, 2926, 2856, 1691, 1620, 1592, 1431, $1369 \mathrm{~cm}^{-1} ;{ }^{1} \mathrm{H}$ and ${ }^{13} \mathrm{C}$ NMR data, Table 2; HRESIMS $\mathrm{m} / \mathrm{z} 699.4533[\mathrm{M}-\mathrm{H}]^{-}$(calcd for $\mathrm{C}_{41} \mathrm{H}_{63} \mathrm{O}_{9}, 699.4472$ )

Ribocyclophane $D(\mathbf{4})$ : white amorphous powder; $[\mathrm{a}]^{25} \mathrm{D}-3(c 0.14, \mathrm{MeOH})$; UV (MeOH) $\lambda_{\max }(\log \varepsilon) 208$ (4.38), 220 (3.85), $280(3.05) \mathrm{nm} ; \mathrm{ECD}(\mathrm{MeOH} 1.0 \mathrm{mM}) \lambda_{\max }(\Delta \varepsilon)$ 211(2.82), 228 (1.21), 284 (0.9); IR (neat) $\nu_{\max } 3380,2931,2862,1625,1433,1372,1256$ $\mathrm{cm}^{-1} ;{ }^{1} \mathrm{H}$ and ${ }^{13} \mathrm{C}$ NMR data, Table 3; HRESIMS $\mathrm{m} / \mathrm{z} 757.4548[\mathrm{M}-\mathrm{H}]^{-}$(calcd for $\mathrm{C}_{43} \mathrm{H}_{65} \mathrm{O}_{11}, 757.4526$ )

Ribocyclophane $E(\mathbf{5})$ : white amorphous powder; $[a]^{25}{ }_{\mathrm{D}}+7(c 0.14, \mathrm{MeOH}) ; \mathrm{UV}(\mathrm{MeOH})$ $\lambda_{\max }(\log \varepsilon) 211$ (3.82), $223(3.61), 278(2.98) \mathrm{nm} ; \mathrm{ECD}(\mathrm{MeOH} 0.7 \mathrm{mM}) \lambda_{\max }(\Delta \varepsilon) 208$ (2.12), 226 (1.12), 277 (-0.8); IR (neat) $v_{\max } 3405,2930,2858,1567,1426,1387,1257$, $830 \mathrm{~cm}^{-1} ;{ }^{1} \mathrm{H}$ and ${ }^{13} \mathrm{C}$ NMR data, Table 3; HRESIMS $\mathrm{m} / \mathrm{z} 793.4310[\mathrm{M}-\mathrm{H}]^{-}$(calcd for $\mathrm{C}_{43} \mathrm{H}_{66} \mathrm{ClO}_{11}, 793.4293$ )

\section{Single Crystal X-ray Crystallographic Analysis of 1}

A small single crystal, roughly $10 \times 10 \times 30 \mu \mathrm{m}$, was encased in Paratone-N oil and cooled to $100 \mathrm{~K}$ in a nylon loop. Data was collected at the Advanced Photon Source, LS-CAT, sector 21, on a MAR 300mm CCD detector. 240 images of width $1^{\circ}$ were collected at a crystal-todetector distance of $91 \mathrm{~mm}$, and wavelength $0.77 \AA$, to a resolution of $0.8 \AA$. The images were indexed, and the intensities were integrated and scaled with XDS. ${ }^{21}$ The unit cell is monoclinic, space group $\mathrm{P} 2{ }_{1}$, with two molecules in the asymmetric unit, and eight disordered $\mathrm{MeOH}$ molecules. The structure was solved by SHELXS, and refined with SHELXL. ${ }^{22}$ Crystal data: $2 \mathrm{C}_{46} \mathrm{H}_{72} \mathrm{O}_{14} \cdot 8 \mathrm{C}_{2} \mathrm{H}_{6} \mathrm{O}$, monoclinic, space group $P 2_{1}$ (No. 4), $a=$ 10.752 (2) $\AA, \quad b=34.601$ (4) $\AA, c=16.762$ (2) $\AA, \beta=90.480(8)^{\circ}, \mathrm{V}=6235.7$ (16) $\AA^{3}, \mathrm{Z}=$ $4, \mathrm{Dc}=1.10, \mu=0.081, \mathrm{~F} 000=2256$. Reflections collected/unique $=55588 / 23169$ (Rint $=$ 0.0514 ), final $\mathrm{R} 1=0.0996, \mathrm{wR} 2=0.2478$ for reflections with $\mathrm{I}>2 \sigma \mathrm{I} ; \mathrm{R} 1=0.1063, \mathrm{wR} 2=$ 0.2552 for all reflections; goodness-of-fit $=1.019$ for all unique data. Bijvoet analysis: Flack $x=-.4(6)$, Parsons z $=-.24(15)$, Probability P2(true) $=1.000$. Crystallographic data (ID entry CCDC 898167) have been deposited in the Cambridge Crystallographic Data Centre. 


\section{Acid Hydrolysis of 1}

Approximately $5 \mathrm{mg}$ of 1 was hydrolyzed using $1 \mathrm{~N} \mathrm{HCl}(1 \mathrm{~mL})$ at $100{ }^{\circ} \mathrm{C}$ for $1 \mathrm{~h}$. The resulting hydrolysate was air-dried, and extracted with $\mathrm{H}_{2} \mathrm{O}$ and EtOAc to yield the $\mathrm{H}_{2} \mathrm{O}$ $(1.3 \mathrm{mg})$ and EtOAc $(3.9 \mathrm{mg})$ fractions. The negative specific rotation observed for the $\mathrm{H}_{2} \mathrm{O}$ fraction suggested the sugar moiety to be D-ribopyranose: $[a]^{25} \mathrm{D}-9\left(c 0.13, \mathrm{H}_{2} \mathrm{O}\right)$. Reversed-phase HPLC of the EtOAc fraction $\left(C_{18}, 60-80 \%\right.$ aqueous $\left.\mathrm{MeOH}\right)$ yielded the pure aglycone moiety $\left(0.5 \mathrm{mg}\right.$; HRESIMS $\left.\mathrm{m} / \mathrm{z} 583.4113[\mathrm{M}-\mathrm{H}]^{-}\right)$. The ECD spectrum of the aglycone moiety displayed negative Cotton effects at $230 \mathrm{~nm}$ and $280 \mathrm{~nm}$, indicating the same absolute configuration as that reported for cylindrocyclophane A. ${ }^{6}$

\section{Antiproliferative Assay}

The human melanoma cell line MDA-MB-435 and human breast cancer cell line MDAMB-231 were purchased from the American Type Culture Collection. The cells were propagated at $37{ }^{\circ} \mathrm{C}$ in $5 \% \mathrm{CO}_{2}$ in RPMI 1640 medium supplemented with fetal bovine serum $(10 \%)$, penicillin (100 units $/ \mathrm{mL})$ and streptomycin $(100 \mu \mathrm{g} / \mathrm{mL})$. Cells in log phase growth were harvested by trypsinization. A total of 5,000 cells were seeded per well of a 96well plate and incubated overnight at $37{ }^{\circ} \mathrm{C}$ in $5 \% \mathrm{CO}_{2}$. Samples dissolved in DMSO were then sequentially diluted and added to the appropriate wells (total volume $100 \mu \mathrm{L}$ ). Each compound was tested at the following concentrations $(\mu \mathrm{g} / \mathrm{mL}): 25,5.0,1.0,0.2$ and 0.04 . The cells were incubated in the presence of test substance for ninety-six hours at $37{ }^{\circ} \mathrm{C}$ and evaluated for viability with a commercial absorbance assay (CellTiter $96 \mathrm{AQ}_{\text {ueous }}$ One Solution Cell Proliferation Assay, Promega Corp). Activity was expressed as the percentage of viable cells present relative to the negative (solvent) control. The positive control was vinblastine tested at $1 \mathrm{ng} / \mathrm{mL}$, which had $49 \%$ viable cells after treatment.

\section{Supplementary Material}

Refer to Web version on PubMed Central for supplementary material.

\section{Acknowledgments}

This research was supported by PO1 CA125066 from NCI/NIH and T32AT00753, The Office of the Director, National Institutes of Health (OD) National Center for Complementary and Integrative Health (NCCIH) to DS May. We thank Dr. B. Ramirez from Center for Structural Biology at UIC for assistance with NMR experiments. LC-MS analysis was performed at UIC Research Resource Center (RRC) Mass Spectrometry Facility. We acknowledge the use of the Southeast Regional Collaborative Access Team (SER-CAT), beam line 22-BM, for data collection of these small crystals. Use of the Advanced Photon Source at Argonne National Laboratory was supported by the US Department of Energy, Office of Science, Office of Basic Energy Sciences, under Contract No. DEAC02-06CH11357.

\section{References}

1. Tan LT. Phytochemistry. 2007; 68:954-979. [PubMed: 17336349]

2. Van Wagoner RM, Drummond AK, Wright JLC. Adv in Appl Microbiol. 2007; 61:89-217. [PubMed: 17448789]

3. Chlipala GE, Mo S, Orjala J. Curr. Drug Targets. 2012; 12:1654-1673.

4. Moore BS, Chen J, Patterson GML, Moore RE. Tetrahedron. 1992; 48:3001-3006.

5. Chen JL, Moore RE, Patterson GML. J. Org. Chem. 1991; 56:4360-4364.

6. Bui HTN, Jansen R, Pham HTL, Mundt S. J. Nat. Prod. 2006; 69:1379-1383. [PubMed: 17067146] 
7. Chlipala GE, Sturdy M, Krunic A, Lantvit DD, Shen Q, Porter K, Swanson SM, Orjala J. J. Nat. Prod. 2010; 73:1529-1537. [PubMed: 20825206]

8. Kang HS, Santarsiero BD, Kim H, Krunic A, Shen Q, Swanson SM, Chai H, Kinghorn AD, Orjala J. Phytochemistry. 2012; 79:109-115. [PubMed: 22571940]

9. Preisitsch M, Harmrolfs K, Pham HT, Heiden SE, Füssel A, Wiesner C, Pretsch A, SwiateckaHagenbruch M, Niedermeyer TH, Müller R, Mundt S. J. Antibiot. (Tokyo). 2014

10. Luo S, Kang H-S, Krunic A, Chlipala GE, Cai G, Chen W-L, Franzblau SG, Swanson SM, Orjala J. Tetrahedron Lett. 2014; 55:686-689. [PubMed: 25225453]

11. May DS, Chen W, Lantvit DD, Zhang X, Krunic A, Burdette JE, Eustaquio A, Orjala J. J. Nat. Prod. 2017; 80:1073-1080. [PubMed: 28252962]

12. Bobzin S, Moore R. Tetrahedron. 1993; 49:7615-7626.

13. Nakamura H, Hamer Ha, Sirasani G, Balskus EP. J. Am. Chem. Soc. 2012; 134:18518-18521. [PubMed: 23106426]

14. Nakamura H, Wang JX, Balskus EP. Chem. Sci. 2015; 6:3816-3822. [PubMed: 29218151]

15. Preisitsch M, Niedermeyer THJ, Heiden SE, Neidhardt I, Kumpfmüller J, Wurster M, Harmrolfs K, Wiesner C, Enke H, Müller R, Mundt S. J. Nat. Prod. 2016; 79:106-115. [PubMed: 26684177]

16. Nakamura H, Schultz EE, Balskus EP. Nat. Chem. Biol. 2017; 13:916-921. [PubMed: 28671684]

17. Preisitsch M, Heiden SE, Beerbaum M, Niedermeyer THJ, Schneefeld M, Herrmann J, Kumpfmüller J, Thürmer A, Neidhardt I, Wiesner C, Daniel R, Müller R, Bange FC, Schmieder P, Schweder T, Mundt S. Mar. Drugs. 2016; 14:21. [PubMed: 26805858]

18. Falch BS, Konig GM, Wright AD, Sticher O, Angerhofer CK, Pezzuto JM, Bachmann H. Planta Med. 1995; 61:321-328. [PubMed: 7480178]

19. Vijayalakshmi KS, Rao VSR. Carbohydr. Res. 1972; 22(2):413-424.

20. Chlipala G, Mo S, Carcache de Blanco EJ, Ito A, Bazarek S, Orjala J. Pharm. Biol. 2009; 47:5360. [PubMed: 21430788]

21. Kabsch W. J. Appl. Crystallogr. 1993; 26:795-800.

22. Sheldrick GM. Acta Crystallogr. 2008; 64:112-122. 


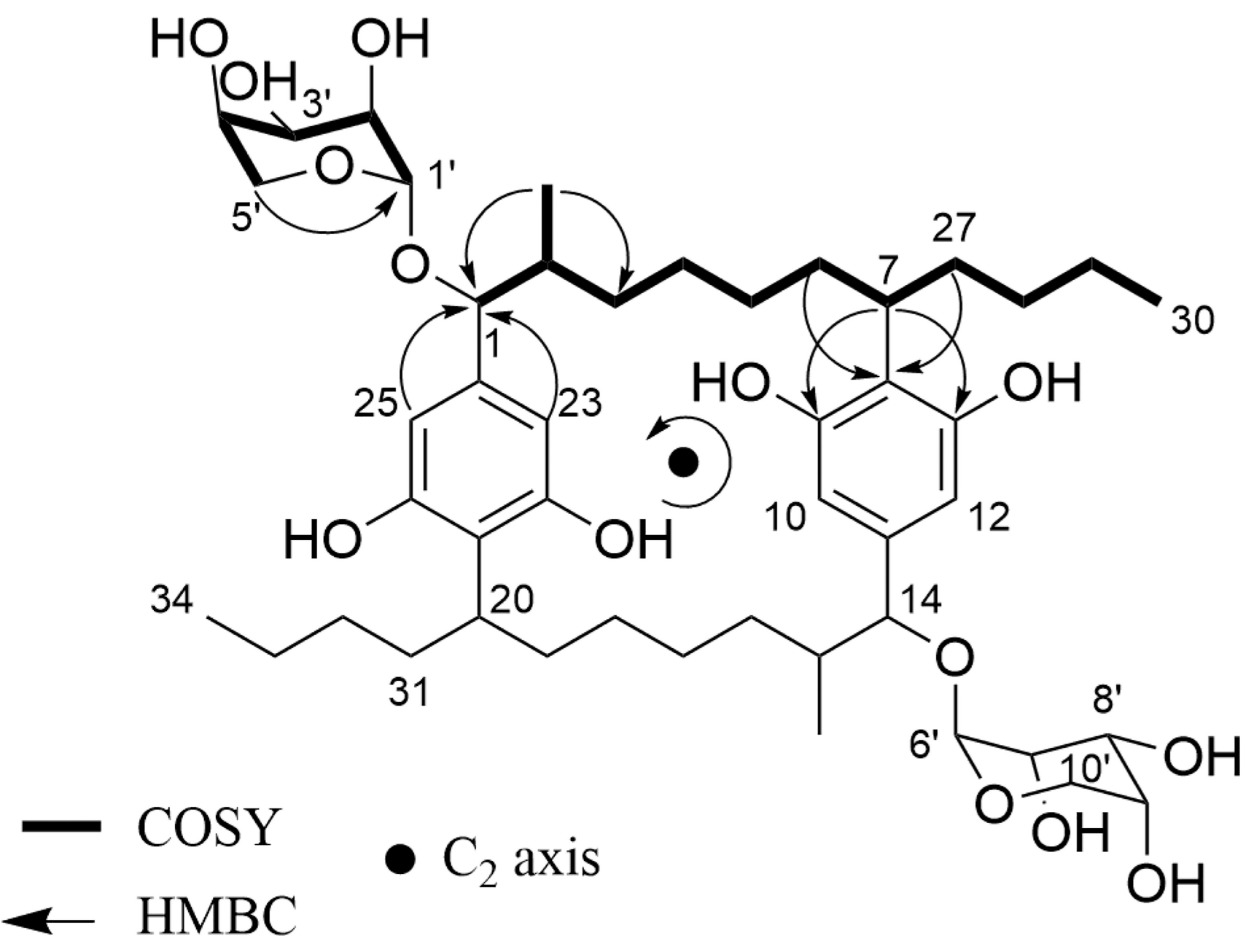

Figure 1.

Key 2D NMR correlations used for the determination of the structure of ribocyclophane A (1). 


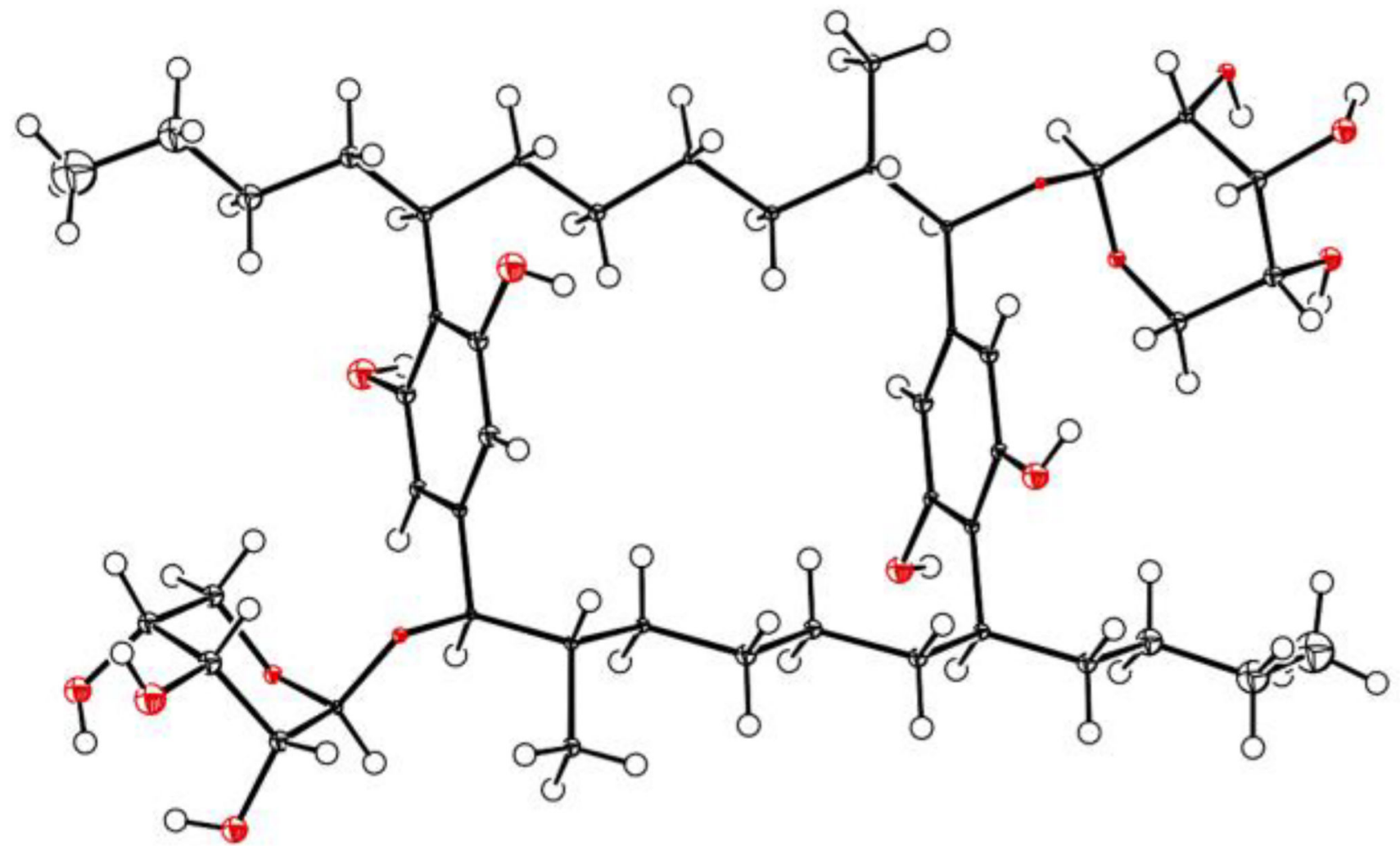

Figure 2.

ORTEP drawing of ribocyclophane A (1). 

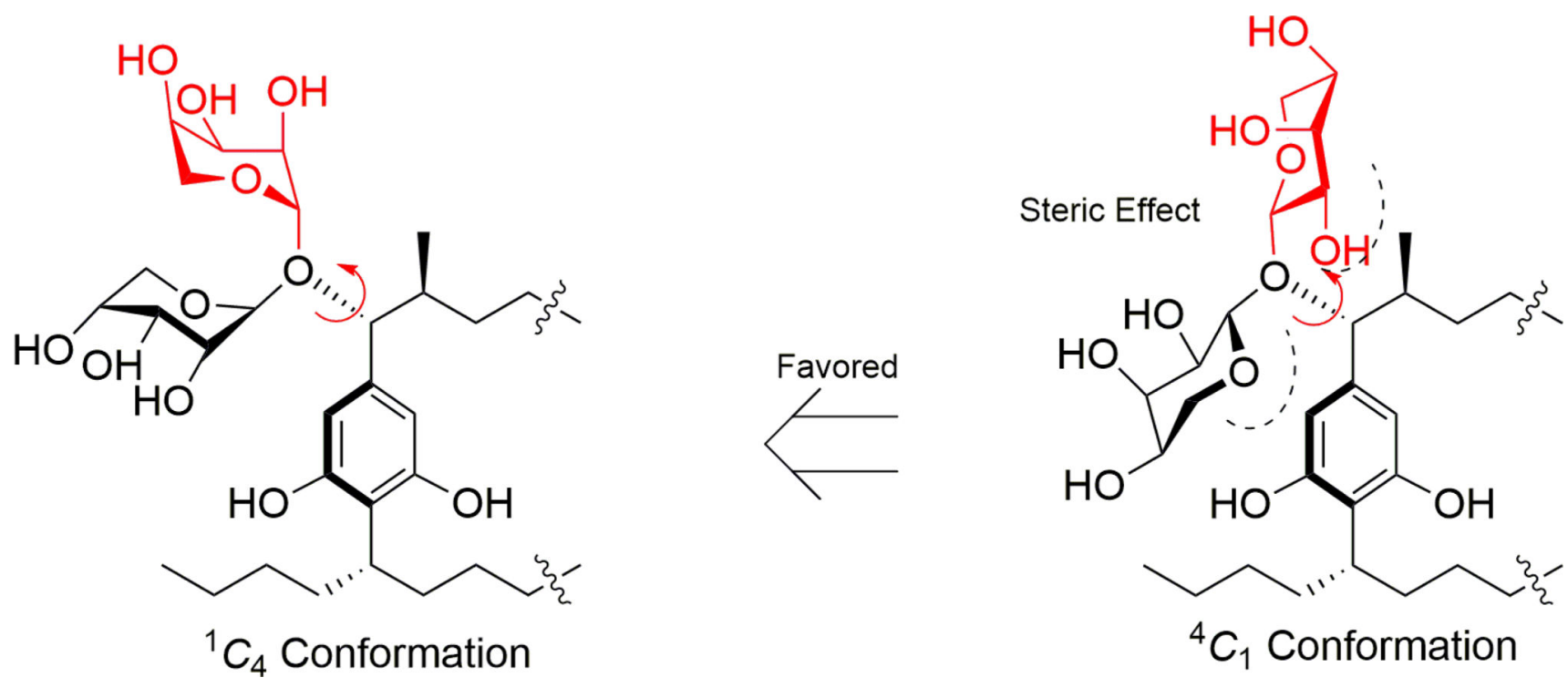

Figure 3.

The $\beta$-D-ribopyranose glycone adopts the less favorable ${ }^{1} C_{4}$ conformation to avoid steric interactions with the cylindrocyclophane aglycone moiety. 

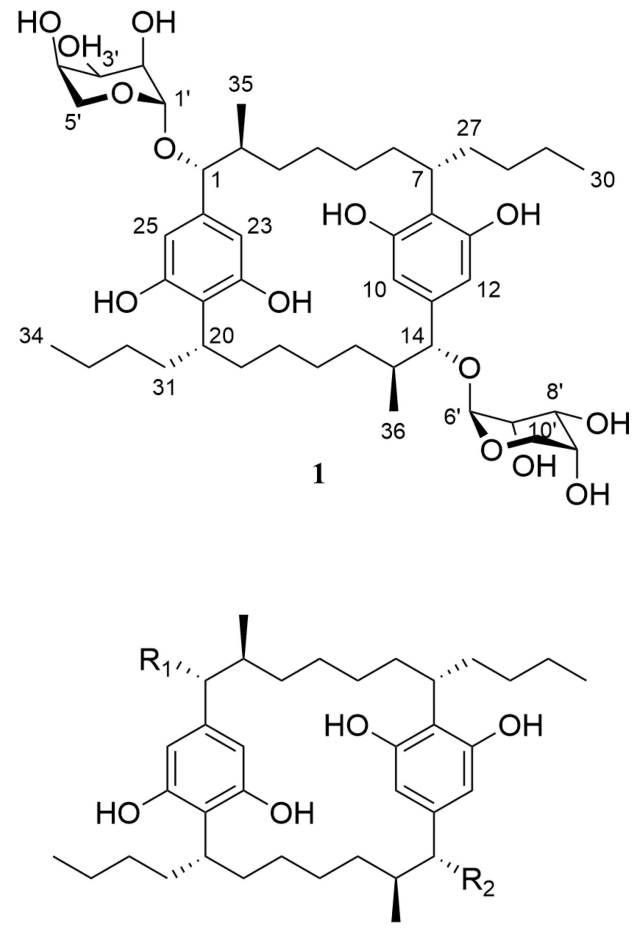
$2 \mathbf{R}_{1}=$ Ribose, $\mathrm{R}_{2}=\mathrm{OH}$
$3 \quad R_{1}=$ Ribose, $R_{2}=H$
$4 \mathbf{R}_{1}=$ Ribose, $R_{2}=$ OAc
$6 R_{1}=$ OAc, $R_{2}=$ OAc

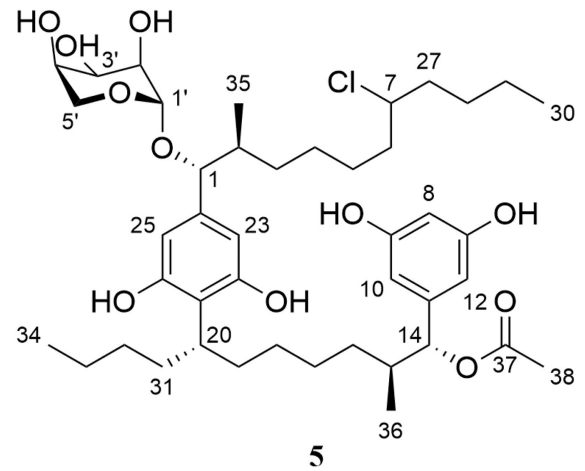


Table 1

NMR Spectroscopic Data of Ribocyclophane A (1) in MeOH- $d_{4}$

\begin{tabular}{|c|c|c|c|c|}
\hline \multirow{2}{*}{ No. } & \multicolumn{4}{|c|}{ Ribocyclophane A (1) } \\
\hline & $\delta_{\mathrm{C}},{ }^{a}$ type & $\delta_{\mathrm{H}},{ }^{b}$ mult. $(\mathrm{J}$ in $\mathrm{Hz})$ & $\operatorname{COSY}^{b}$ & HMBC $^{b}$ \\
\hline $1 / 14$ & $90.1, \mathrm{CH}$ & $3.65, \mathrm{~d}(12.2$ & $2 / 15$ & $2 / 15,3 / 16,10 / 23,11 / 24,12 / 25,35 / 36,1^{\prime} / 6$ ' \\
\hline $2 / 15$ & $41.8, \mathrm{CH}$ & $1.65, \mathrm{~m}$ & $1 / 14,3 / 16,35 / 36$ & $\mathrm{NA}^{c}$ \\
\hline $3 / 16$ & $34.9, \mathrm{CH}_{2}$ & $\begin{array}{l}0.66, \mathrm{~m} \\
0.75, \mathrm{~m}\end{array}$ & $2 / 15,4 / 17$ & $\mathrm{NA}^{d}$ \\
\hline $4 / 17$ & $30.0, \mathrm{CH}_{2}$ & $\begin{array}{l}0.82, \mathrm{~m} \\
1.44, \mathrm{~m}\end{array}$ & $3 / 16,5 / 18$ & $\mathrm{NA}^{c}$ \\
\hline $5 / 18$ & $30.9, \mathrm{CH}_{2}$ & $\begin{array}{l}0.71, \mathrm{~m} \\
0.96, \mathrm{~m}\end{array}$ & $4 / 17,6 / 19$ & $\mathrm{NA}^{d}$ \\
\hline $6 / 19$ & $35.5, \mathrm{CH}_{2}$ & $\begin{array}{c}1.32, \mathrm{~m} \\
2.03, \mathrm{ddd}(4.2)\end{array}$ & $5 / 18,7 / 20$ & $4 / 17,5 / 18,7 / 20,27 / 31$ \\
\hline $7 / 20$ & $37.0, \mathrm{CH}$ & $3.16, \mathrm{~m}$ & $6 / 19,27 / 31$ & $5 / 18,6 / 19,8 / 21,9 / 22,13 / 26,27 / 31,28 / 32$ \\
\hline $8 / 21$ & $117.9, \mathrm{C}$ & & & \\
\hline $9 / 22$ & $158.9, \mathrm{C}$ & & & \\
\hline $10 / 23$ & $105.5, \mathrm{CH}$ & $6.19, \mathrm{~s}$ & & $1 / 14,12 / 25,8 / 21,9 / 22$ \\
\hline $11 / 24$ & 142.1, C & & & \\
\hline $12 / 25$ & $109.3, \mathrm{CH}$ & $6.09, \mathrm{~s}$ & & $1 / 14,10 / 23,8 / 21,13 / 26$ \\
\hline $13 / 26$ & 157.1, C & & & \\
\hline $27 / 31$ & $34.8, \mathrm{CH}_{2}$ & $\begin{array}{l}1.47, \mathrm{~m} \\
1.95, \mathrm{~m}\end{array}$ & $7 / 20,28 / 32$ & $6 / 19,7 / 20,8 / 21,28 / 32,29 / 33$ \\
\hline $28 / 32$ & $31.9, \mathrm{CH}_{2}$ & $\begin{array}{l}1.04, \mathrm{~m} \\
1.17, \mathrm{~m}\end{array}$ & $27 / 31,29 / 33$ & $\mathrm{NA}^{d}$ \\
\hline $29 / 33$ & 24.0, $\mathrm{CH}_{2}$ & $\begin{array}{l}1.18, \mathrm{~m} \\
1.28, \mathrm{~m}\end{array}$ & $28 / 32,30 / 34$ & $\mathrm{NA}^{d}$ \\
\hline $30 / 34$ & $14.8, \mathrm{CH}_{3}$ & $0.79, \mathrm{t}(7.2)$ & $29 / 33$ & $28 / 32,29 / 33$ \\
\hline $35 / 36$ & $16.7, \mathrm{CH}_{3}$ & $1.05, \mathrm{~d}(6.0)$ & $2 / 15$ & $1 / 14,2 / 15,3 / 16$ \\
\hline $1^{\prime} / 6$ & 104.6, CH & $4.85, \mathrm{~d}(1.8)$ & $2^{\prime} / 7$ & $1 / 14,5^{\prime} / 10^{\prime}, 2^{\prime} / 7,3^{\prime} / 8^{\prime}$ \\
\hline $2^{\prime} / 7$ & $72.8, \mathrm{CH}$ & $3.73, \mathrm{~d}(1.8,3.0)$ & $1^{\prime} / 6^{\prime}, 3^{\prime} / 8^{\prime}$ & $\mathrm{NA}^{c}$ \\
\hline $3^{\prime} / 8^{\prime}$ & $66.9, \mathrm{CH}$ & $3.70, \mathrm{t}(3.0)$ & $2^{\prime} / 7^{\prime}, 4^{\prime} / 9^{\prime}$ & $\mathrm{NA}^{c}$ \\
\hline $4^{\prime} / 9^{\prime}$ & 71.6, $\mathrm{CH}$ & 3.59 , ddd $(2.4,3.0)$ & $3^{\prime} / 8^{\prime}, 5^{\prime} / 10^{\prime}$ & $\mathrm{NA}^{c}$ \\
\hline $5 / 10$ & 65.6, $\mathrm{CH}_{2}$ & $\begin{array}{c}3.19, \mathrm{dd}(12.6,2.4) \\
3.30, \mathrm{dd}(12.6)\end{array}$ & $4^{\prime} / 9$ ' & $1^{\prime} / 6^{\prime}, 3^{\prime} / 8^{\prime}, 4^{\prime} / 9^{\prime}$ \\
\hline
\end{tabular}


Table 2

NMR Spectroscopic Data of Ribocyclophanes B (2) and C (3) in MeOH- $d_{4}$

\begin{tabular}{|c|c|c|c|c|}
\hline \multirow{2}{*}{ No. } & \multicolumn{2}{|c|}{ Ribocyclophane B (2) } & \multicolumn{2}{|c|}{ Ribocyclophane C (3) } \\
\hline & $\delta_{\mathrm{C}},{ }^{a, b}$ type & $\delta_{\mathrm{H}}^{b}$, mult. $(J$ in $\mathrm{Hz})$ & $\delta_{\mathrm{C}},{ }^{a, b}$ type & $\delta_{\mathrm{H}}^{b}$, mult. $(J$ in $\mathrm{Hz})$ \\
\hline 1 & $88.5, \mathrm{CH}$ & $3.65, \mathrm{~d}(10.2)$ & $88.4, \mathrm{CH}$ & $3.66, \mathrm{~d}(10.2)$ \\
\hline 2 & $40.1, \mathrm{CH}$ & $1.66, \mathrm{~m}$ & $40.1, \mathrm{CH}$ & $1.66, \mathrm{~m}$ \\
\hline 3 & $33.4, \mathrm{CH}_{2}$ & $\begin{array}{l}0.65, \mathrm{~m} \\
0.76, \mathrm{~m}\end{array}$ & $33.3, \mathrm{CH}_{2}$ & $\begin{array}{l}0.66, \mathrm{~m} \\
0.79, \mathrm{~m}\end{array}$ \\
\hline 4 & 28.6, $\mathrm{CH}_{2}$ & $\begin{array}{l}0.83, \mathrm{~m} \\
1.42, \mathrm{~m}\end{array}$ & 28.6, $\mathrm{CH}_{2}$ & $\begin{array}{l}0.81, \mathrm{~m} \\
1.43, \mathrm{~m}\end{array}$ \\
\hline 5 & $29.0, \mathrm{CH}_{2}$ & $\begin{array}{l}0.72, \mathrm{~m} \\
0.95, \mathrm{~m}\end{array}$ & 29.3, $\mathrm{CH}_{2}$ & $\begin{array}{l}0.74, \mathrm{~m} \\
0.97, \mathrm{~m}\end{array}$ \\
\hline 6 & $33.9, \mathrm{CH}_{2}$ & $\begin{array}{l}1.32, \mathrm{~m} \\
2.04, \mathrm{~m}\end{array}$ & $34.0, \mathrm{CH}_{2}$ & $\begin{array}{l}1.32, \mathrm{~m} \\
2.00, \mathrm{~m}\end{array}$ \\
\hline 7 & $35.4, \mathrm{CH}$ & $3.16, \mathrm{~m}$ & $35.4, \mathrm{CH}$ & $3.11, \mathrm{~m}$ \\
\hline 8 & $116.1, \mathrm{C}$ & & $114.7, \mathrm{C}$ & \\
\hline 9 & 157.7, C & & $156.9, \mathrm{C}$ & \\
\hline 10 & $103.5, \mathrm{CH}$ & $6.24, \mathrm{~s}$ & $106.5, \mathrm{CH}$ & $6.02, \mathrm{~s}$ \\
\hline 11 & $142.2, \mathrm{C}$ & & $139.4, \mathrm{C}$ & \\
\hline 12 & 107.6, CH & $6.07, \mathrm{~s}$ & $108.5, \mathrm{CH}$ & $5.97, \mathrm{~s}$ \\
\hline 13 & 156.0, C & & 155.7, C & \\
\hline 14 & $80.2, \mathrm{CH}$ & $3.74, \mathrm{~d}(9.6)$ & $44.3, \mathrm{CH}_{2}$ & $\begin{array}{c}1.81, \mathrm{t}(12.6) \\
2.61, \mathrm{dd} 13.2,3.6)\end{array}$ \\
\hline 15 & $40.7, \mathrm{CH}$ & $1.56, \mathrm{~m}$ & $35.4, \mathrm{CH}$ & $1.57, \mathrm{~m}$ \\
\hline 16 & $33.4, \mathrm{CH}_{2}$ & $\begin{array}{l}0.65, \mathrm{~m} \\
0.76, \mathrm{~m}\end{array}$ & $35.3, \mathrm{CH}_{2}$ & $\begin{array}{l}0.62, \mathrm{~m} \\
1.01, \mathrm{~m}\end{array}$ \\
\hline 17 & 28.6, $\mathrm{CH}_{2}$ & $\begin{array}{l}0.83, \mathrm{~m} \\
1.42, \mathrm{~m}\end{array}$ & $28.8, \mathrm{CH}_{2}$ & $\begin{array}{l}0.81, \mathrm{~m} \\
1.34, \mathrm{~m}\end{array}$ \\
\hline 18 & $29.0, \mathrm{CH}_{2}$ & $\begin{array}{l}0.72, \mathrm{~m} \\
0.95, \mathrm{~m}\end{array}$ & 29.3, $\mathrm{CH}_{2}$ & $\begin{array}{l}0.74, \mathrm{~m} \\
0.97, \mathrm{~m}\end{array}$ \\
\hline 19 & $33.9, \mathrm{CH}_{2}$ & $\begin{array}{l}1.32, \mathrm{~m} \\
2.04, \mathrm{~m}\end{array}$ & 34.0, $\mathrm{CH}_{2}$ & $\begin{array}{l}1.32, \mathrm{~m} \\
2.00, \mathrm{~m}\end{array}$ \\
\hline 20 & $35.4, \mathrm{CH}$ & $3.16, \mathrm{~m}$ & $35.4, \mathrm{CH}$ & $3.16, \mathrm{~m}$ \\
\hline 21 & $116.1, \mathrm{C}$ & & $116.4, \mathrm{C}$ & \\
\hline 22 & 157.7, C & & 157.2, C & \\
\hline 23 & $103.7, \mathrm{CH}$ & $6.20, \mathrm{~s}$ & $103.9, \mathrm{CH}$ & $6.20, \mathrm{~s}$ \\
\hline 24 & $140.4, \mathrm{C}$ & & $140.3, \mathrm{C}$ & \\
\hline 25 & $107.8, \mathrm{CH}$ & $6.09, \mathrm{~s}$ & 107.6, CH & $6.09, \mathrm{~s}$ \\
\hline 26 & $155.0, \mathrm{C}$ & & $155.7, \mathrm{C}$ & \\
\hline 27 & $33.3, \mathrm{CH}_{2}$ & $\begin{array}{l}1.47, \mathrm{~m} \\
1.95, \mathrm{~m}\end{array}$ & $33.3, \mathrm{CH}_{2}$ & $\begin{array}{l}1.48, \mathrm{~m} \\
1.94, \mathrm{~m}\end{array}$ \\
\hline
\end{tabular}

J Nat Prod. Author manuscript; available in PMC 2019 March 23. 


\begin{tabular}{|c|c|c|c|c|}
\hline \multirow{2}{*}{ No. } & \multicolumn{2}{|c|}{ Ribocyclophane B (2) } & \multicolumn{2}{|c|}{ Ribocyclophane C (3) } \\
\hline & $\delta_{\mathrm{C}}, a, b$ type & $\delta_{\mathrm{H}}^{b}$, mult. $(J$ in Hz$)$ & $\delta_{\mathrm{C}}, a, b$ type & $\delta_{\mathrm{H}}^{b}$, mult. $(J$ in $\mathrm{Hz})$ \\
\hline \multirow{2}{*}{28} & \multirow{2}{*}{$30.2, \mathrm{CH}_{2}$} & & \multirow{2}{*}{$30.3, \mathrm{CH}_{2}$} & $1.06, \mathrm{~m}$ \\
\hline & & $1.17, \mathrm{~m}$ & & $1.17, \mathrm{~m}$ \\
\hline \multirow{2}{*}{29} & \multirow{2}{*}{$22.4, \mathrm{CH}_{2}$} & $1.19, \mathrm{~m}$ & \multirow{2}{*}{$22.3, \mathrm{CH}_{2}$} & $1.20, \mathrm{~m}$ \\
\hline & & $1.29, \mathrm{~m}$ & & $1.29, \mathrm{~m}$ \\
\hline 30 & $13.1, \mathrm{CH}_{3}$ & $0.79, \mathrm{t}(7.2)$ & $13.1, \mathrm{CH}_{3}$ & $0.82, \mathrm{t}(7.2)$ \\
\hline \multirow{2}{*}{31} & \multirow{2}{*}{$33.3, \mathrm{CH}_{2}$} & $1.47, \mathrm{~m}$ & \multirow{2}{*}{$33.3, \mathrm{CH}_{2}$} & $1.48, \mathrm{~m}$ \\
\hline & & $1.95, \mathrm{~m}$ & & $1.94, \mathrm{~m}$ \\
\hline \multirow{2}{*}{32} & \multirow{2}{*}{$30.2, \mathrm{CH}_{2}$} & $1.04, \mathrm{~m}$ & \multirow{2}{*}{$30.3, \mathrm{CH}_{2}$} & $1.06, \mathrm{~m}$ \\
\hline & & $1.17, \mathrm{~m}$ & & $1.17, \mathrm{~m}$ \\
\hline \multirow{2}{*}{33} & \multirow{2}{*}{$22.4, \mathrm{CH}_{2}$} & $1.19, \mathrm{~m}$ & \multirow{2}{*}{$22.3, \mathrm{CH}_{2}$} & $1.20, \mathrm{~m}$ \\
\hline & & $1.29, \mathrm{~m}$ & & $1.29, \mathrm{~m}$ \\
\hline 34 & $13.1, \mathrm{CH}_{3}$ & $0.79, \mathrm{t}(7.2)$ & $13.3, \mathrm{CH}_{3}$ & $0.79, \mathrm{t}(7.2)$ \\
\hline 35 & $15.4, \mathrm{CH}_{3}$ & $1.05, \mathrm{~d}(7.2)$ & $15.4, \mathrm{CH}_{3}$ & $1.05, \mathrm{~d}(6.6)$ \\
\hline 36 & $15.4, \mathrm{CH}_{3}$ & $1.06, \mathrm{~d}(6.6)$ & $19.3, \mathrm{CH}_{3}$ & $0.95, \mathrm{~d}(6.6)$ \\
\hline 1 ' & 103.0, CH & $4.85, \mathrm{~d}(2.4)$ & 103.0, CH & $4.85, \mathrm{~d}(2.4)$ \\
\hline 2 ' & $71.1, \mathrm{CH}$ & 3.73 , brs & $71.1, \mathrm{CH}$ & 3.73 , brs \\
\hline $3^{\prime}$ & $65.2, \mathrm{CH}$ & $3.70, \mathrm{t}(3.0)$ & $65.3, \mathrm{CH}$ & $3.70, \mathrm{t}(3.0)$ \\
\hline $4^{\prime}$ & $70.1, \mathrm{CH}$ & 3.60, brs & $70.0, \mathrm{CH}$ & 3.59, brs \\
\hline \multirow{2}{*}{5 ' } & \multirow{2}{*}{$63.9, \mathrm{CH}_{2}$} & $3.20, \mathrm{dd}(12.6,2.4)$ & \multirow{2}{*}{$64.0, \mathrm{CH}_{2}$} & $3.20, \mathrm{dd}(12.6,2.4)$ \\
\hline & & 3.31, overlapped & & 3.31 , overlapped \\
\hline
\end{tabular}

a assigned from the HSQC and HMBC spectra,

$b_{\text {recorded at } 600 \mathrm{MHz}}$

\section{recorded at $600 \mathrm{MHz}$}


Table 3

NMR Spectroscopic Data of Ribocyclophanes D (4) and E (5) in MeOH- $d_{4}$

\begin{tabular}{|c|c|c|c|c|}
\hline \multirow{2}{*}{ No. } & \multicolumn{2}{|c|}{ Ribocyclophane D (4) } & \multicolumn{2}{|c|}{ Ribocyclophane E (5) } \\
\hline & $\delta_{\mathrm{C}}{ }^{a}$, type & $\delta_{\mathrm{H}}^{c}$, mult. $(J$ in $\mathrm{Hz})$ & $\delta_{\mathrm{C}}, b$ type & $\delta_{\mathrm{H}}^{c}$, mult. $(J$ in Hz) \\
\hline 1 & $90.1, \mathrm{CH}$ & $3.65, \mathrm{~d}(10.0)$ & $87.6, \mathrm{CH}$ & $4.0, \mathrm{~m}$ \\
\hline 2 & $41.7, \mathrm{CH}$ & $1.64, \mathrm{~m}$ & $40.4, \mathrm{CH}$ & $1.77, \mathrm{~m}$ \\
\hline 3 & $34.9, \mathrm{CH}_{2}$ & $\begin{array}{l}0.65, \mathrm{~m} \\
0.76, \mathrm{~m}\end{array}$ & $33.9, \mathrm{CH}_{2}$ & $\begin{array}{l}0.97, \mathrm{~m} \\
1.26, \mathrm{~m}\end{array}$ \\
\hline 4 & $30.0, \mathrm{CH}_{2}$ & $\begin{array}{l}0.84, \mathrm{~m} \\
1.43, \mathrm{~m}\end{array}$ & $22.7, \mathrm{CH}_{2}$ & $1.32, \mathrm{~m}$ \\
\hline 5 & $30.8, \mathrm{CH}_{2}$ & $\begin{array}{c}0.7, \mathrm{~m} \\
0.94, \mathrm{~m}\end{array}$ & 27.6, $\mathrm{CH}_{2}$ & $\begin{array}{l}1.33, \mathrm{~m} \\
1.44, \mathrm{~m}\end{array}$ \\
\hline 6 & $35.5, \mathrm{CH}_{2}$ & $\begin{array}{l}1.33, \mathrm{~m} \\
2.03, \mathrm{~m}\end{array}$ & $39.4, \mathrm{CH}_{2}$ & $\begin{array}{l}1.54, \mathrm{~m} \\
1.62, \mathrm{~m}\end{array}$ \\
\hline 7 & $37.0, \mathrm{CH}$ & $3.16, \mathrm{~m}$ & $65.1, \mathrm{CH}$ & $3.83, \mathrm{~m}$ \\
\hline 8 & $118.7, \mathrm{C}$ & & $102.7, \mathrm{CH}$ & $6.15, \mathrm{~s}$ \\
\hline 9 & 159.0, C & & 159.9, C & \\
\hline 10 & 109.6, CH & $6.13, \mathrm{~s}$ & 106.0, $\mathrm{CH}$ & $6.17, \mathrm{~s}$ \\
\hline 11 & $139.3, \mathrm{C}$ & & 144.1, C & \\
\hline 12 & $105.3, \mathrm{CH}$ & $6.18, \mathrm{~s}$ & 106.0, $\mathrm{CH}$ & $6.17, \mathrm{~s}$ \\
\hline 13 & 157.1, C & & $159.9, \mathrm{C}$ & \\
\hline 14 & 83.6, $\mathrm{CH}$ & $5.0, \mathrm{~d}(10.4)$ & $80.8, \mathrm{CH}$ & $5.4, \mathrm{~m}$ \\
\hline 15 & $40.2, \mathrm{CH}$ & $1.77, \mathrm{~m}$ & $39.9, \mathrm{CH}$ & $1.79, \mathrm{~m}$ \\
\hline 16 & $34.6, \mathrm{CH}_{2}$ & $\begin{array}{l}0.71, \mathrm{~m} \\
0.78, \mathrm{~m}\end{array}$ & $30.6, \mathrm{CH}_{2}$ & $1.29, \mathrm{~m}$ \\
\hline 17 & $29.8, \mathrm{CH}_{2}$ & $\begin{array}{l}0.84, \mathrm{~m} \\
1.43, \mathrm{~m}\end{array}$ & $29.8, \mathrm{CH}_{2}$ & $\begin{array}{l}1.05, \mathrm{~m} \\
1.34, \mathrm{~m}\end{array}$ \\
\hline 18 & $30.7, \mathrm{CH}_{2}$ & $\begin{array}{c}0.7, \mathrm{~m} \\
0.94, \mathrm{~m}\end{array}$ & 29.6, $\mathrm{CH}_{2}$ & $1.09, \mathrm{~m}$ \\
\hline 19 & $35.4, \mathrm{CH}_{2}$ & $\begin{array}{l}1.33, \mathrm{~m} \\
2.03, \mathrm{~m}\end{array}$ & $34.5, \mathrm{CH}_{2}$ & $\begin{array}{l}1.47, \mathrm{~m} \\
1.92, \mathrm{~m}\end{array}$ \\
\hline 20 & $37.0, \mathrm{CH}$ & $3.16, \mathrm{~m}$ & $36.4, \mathrm{CH}$ & $3.19, \mathrm{~m}$ \\
\hline 21 & $117.8, \mathrm{C}$ & & $118.2, \mathrm{C}$ & \\
\hline 22 & 159.0, C & & $158.3, \mathrm{C}$ & \\
\hline 23 & $105.5, \mathrm{CH}$ & $6.2, \mathrm{~s}$ & 107.3, CH & $6.22, \mathrm{br}$ \\
\hline 24 & $142.1, \mathrm{C}$ & & $141.9, \mathrm{C}$ & \\
\hline 25 & $109.2, \mathrm{CH}$ & $6.08, \mathrm{~s}$ & 107.3, CH & $6.22, \mathrm{br}$ \\
\hline 26 & 157.1, C & & $158.3, \mathrm{C}$ & \\
\hline 27 & $35.0, \mathrm{CH}_{2}$ & $\begin{array}{l}1.49, \mathrm{~m} \\
1.91, \mathrm{~m}\end{array}$ & $39.4, \mathrm{CH}_{2}$ & $\begin{array}{c}1.6, \mathrm{~m} \\
1.68, \mathrm{~m}\end{array}$ \\
\hline 28 & $31.8, \mathrm{CH}_{2}$ & $1.05, \mathrm{~m}$ & 27.6, $\mathrm{CH}_{2}$ & $1.29, \mathrm{~m}$ \\
\hline
\end{tabular}

J Nat Prod. Author manuscript; available in PMC 2019 March 23. 


\begin{tabular}{|c|c|c|c|c|}
\hline \multirow{2}{*}{ No. } & \multicolumn{2}{|c|}{ Ribocyclophane D (4) } & \multicolumn{2}{|c|}{ Ribocyclophane E (5) } \\
\hline & $\delta_{\mathrm{C}}{ }^{a}$, type & $\delta_{\mathrm{H}}^{c}$, mult. $(J$ in $\mathrm{Hz})$ & $\delta_{\mathrm{C}},{ }^{b}$ type & $\delta_{\mathrm{H}}^{c}$, mult. $(J$ in $\mathrm{Hz})$ \\
\hline \multirow{3}{*}{29} & \multirow{3}{*}{$24.0, \mathrm{CH}_{2}$} & $1.17, \mathrm{~m}$ & & $1.34, \mathrm{~m}$ \\
\hline & & $1.19, \mathrm{~m}$ & \multirow{2}{*}{$23.4, \mathrm{CH}_{2}$} & $1.27, \mathrm{~m}$ \\
\hline & & $1.29, \mathrm{~m}$ & & $1.33, \mathrm{~m}$ \\
\hline 30 & $14.8, \mathrm{CH}_{3}$ & $0.79, \mathrm{t}(7.3)$ & $14.3, \mathrm{CH}_{3}$ & $0.92, \mathrm{t}(7.3)$ \\
\hline \multirow{2}{*}{31} & \multirow{2}{*}{$34.8, \mathrm{CH}_{2}$} & $1.49, \mathrm{~m}$ & \multirow{2}{*}{$34.5, \mathrm{CH}_{2}$} & $1.5, \mathrm{~m}$ \\
\hline & & $1.95, \mathrm{~m}$ & & $1.94, \mathrm{~m}$ \\
\hline \multirow{2}{*}{32} & \multirow{2}{*}{$31.9, \mathrm{CH}_{2}$} & $1.05, \mathrm{~m}$ & \multirow{2}{*}{$31.7, \mathrm{CH}_{2}$} & $1.07, \mathrm{~m}$ \\
\hline & & $1.17, \mathrm{~m}$ & & $1.17, \mathrm{~m}$ \\
\hline \multirow{2}{*}{33} & \multirow{2}{*}{$24.1, \mathrm{CH}_{2}$} & $1.22, \mathrm{~m}$ & \multirow{2}{*}{$23.8, \mathrm{CH}_{2}$} & $1.22, \mathrm{~m}$ \\
\hline & & $1.29, \mathrm{~m}$ & & $1.30, \mathrm{~m}$ \\
\hline 34 & $14.7, \mathrm{CH}_{3}$ & $0.82, \mathrm{t}(7.3)$ & $15.1, \mathrm{CH}_{3}$ & $0.82, \mathrm{t}(7.2)$ \\
\hline 35 & $17.0, \mathrm{CH}_{3}$ & $1.05, \mathrm{~d}(6.4)$ & $16.5, \mathrm{CH}_{3}$ & $0.99, \mathrm{~d}(6.5)$ \\
\hline 36 & $16.7, \mathrm{CH}_{3}$ & $0.96, \mathrm{~d}(6.4)$ & $14.8, \mathrm{CH}_{3}$ & $0.85, \mathrm{~d}(6.5)$ \\
\hline 37 & $172.6, \mathrm{C}$ & & 173.1, C & \\
\hline 38 & $21.3, \mathrm{CH}_{3}$ & $2.0, \mathrm{~s}$ & $21.2, \mathrm{CH}_{3}$ & $2.07, \mathrm{~s}$ \\
\hline 1 ' & $104.5, \mathrm{CH}$ & $4.85, \mathrm{~d}(2.0)$ & $103.8, \mathrm{CH}$ & $4.89, \mathrm{br}$ \\
\hline 2 & $72.8, \mathrm{CH}$ & 3.72 , brs & $72.6, \mathrm{CH}$ & $3.76, \mathrm{br}$ \\
\hline 3 & $67, \mathrm{CH}$ & $3.7, \mathrm{t}(3.2)$ & $66.9, \mathrm{CH}$ & $3.78, \mathrm{br}$ \\
\hline $4^{\prime}$ & 71.6, CH & 3.6 , brs & $71.3, \mathrm{CH}$ & $3.67, \mathrm{br}$ \\
\hline \multirow{2}{*}{5} & \multirow{2}{*}{$65.7, \mathrm{CH}_{2}$} & $3.2, \mathrm{dd}(12.3,2.5)$ & \multirow{2}{*}{$65.6, \mathrm{CH}_{2}$} & 3.32 , overlapped \\
\hline & & 3.32, overlapped & & 3.47, overlapped \\
\hline
\end{tabular}

$a$ assigned from the DEPT-Q spectrum acquired at $226 \mathrm{MHz}$,

$b$ assigned from HSCQ and HMBC spectra,

${ }^{c}$ recorded at $900 \mathrm{MHz}$ 